\title{
Dependences of the warm-up time changes of catalytic converters in the open storage car conditions
}

\author{
Alexei Zaloznov*1, Nikolay Pevnev ${ }^{1}$ and Liudmila Trofimova ${ }^{1}$ \\ ${ }^{1}$ Siberian State Automobile and Highway University (SibADI), Mira str., 5, Omsk 644080, Russia
}

\begin{abstract}
Annotation. In the article, emphasis made on determining the start operation time of catalytic converter in the open storage car conditions. In this regard, experiments made on author's experimental setup, quantity of which provides a confidence probability 0,95 . Results of experiments allow us to determine the dependences of the warm-up time changes of catalytic converters when the ambient temperature changes from $+1^{\circ} \mathrm{C}$ to $30^{\circ} \mathrm{C}$. The compliance with current regulatory requirements for content of $\mathrm{CO}$ and $\mathrm{CH}$ in engine exhaust provided.
\end{abstract}

\section{Introduction}

The modern three-component automobile catalytic converters are the most important and the most common devices in exhaust cleaning system of internal combustion engines in passengers cars. Features of catalytic converters are that they effectively perform their functions only when it reactor heated to $220-250^{\circ} \mathrm{C}$ and they have low efficiency on coldstart and warm-up modes [1].

Under low temperatures influence the temperature mode of automobile catalytic converters is changes. It explained by increasing heat transfer from surface of the unit to environment. In this regard, the catalytic converters warm-up time is increasing after start and the period of their cooling after stopping is decreasing.

The heating time to efficient temperature of catalytic converter depends on different factors, among which the ambient temperature has a significant influence [2]. In this regard, the task of establishing the dependences of the warm-up time changes of catalytic converters in the open storage car conditions becomes relevant.

\section{Material and methods}

Analytical studies have been conducted with applying the systematic method. In which the non-stationary process of heating of catalytic converters was study and a mathematical model has been developed [3].

\footnotetext{
* Corresponding author: 141zet@,gmail.com
} 
This paper presents experimental studies and their results to determine the influence of ambient air temperature on warm-up time of catalytic converter in the open storage car conditions.

The target of experimental studies is to determine the values of the heating-up time of catalytic converter in the open storage car conditions.

For testing, an experimental installation based on the car LADA VESTA with engine VAZ-21129 has been equipped. General view of the experimental setup fragments is shown in Figures 1-4.

The exhaust cleaning system of engine VAZ-21129 is including exhaust manifold, combined with three-component catalytic converter (Fig. 2, 3).

To measure the temperature of exhaust gases, leaving each of the four engine cylinders and entering, leaving the catalytic converter, thermocouples THA 0006-40.02, produced in JSC "NPP "Etalon", Omsk, have been installed in the body of exhaust manifold and catalytic converter.

To measure the outside temperature of catalytic converter body, two thermocouples ETP-01A have been installed along the middle line of catalytic converter.

All thermocouples have been connected to digital multimeter brand DT-9908, which show value of temperature in degrees Celsius on it display.

Determination of the quantitative and qualitative composition of exhaust gases was carried out using a portable gas analyzer brand "Infracar" M3T.01.

Using the original CODE-X diagnostic software based on the Panasonic Toughbook CF-D1 computer, the necessary technical parameters were monitored, these are mass airfuel flow, excess air ratio, engine crankshaft speed.

The stopwatch was used to measure the time since the internal combustion engine was started.

The equipment and measuring instruments used (gas analyzer "Infracar" M3T.01, digital multimeter brand DT-9908, thermocouples THA 0006-40.02) were subject to metrological control and had valid verification certificates.

The essence of the experiment was as follows:

- the test vehicle was kept in the parking lot until the catalytic converter cooled down (ambient air temperature);

- measurement results were entered in the registration protocol after engine start:

- content of carbon monoxide $(\mathrm{CO})$ and hydrocarbons $(\mathrm{CH})$ in exhaust gases;

- temperature of exhaust gases at the exit from combustion chambers of all four engine cylinders;

- temperature of exhaust gases at the enter in catalytic converter;

- temperature of exhaust gases at the exit from catalytic converter;

- temperature of the catalytic converter body outside;

- $\quad$ engine crankshaft speed;

- excess air ratio value;

- ambient air temperature;

- ambient air pressure;

- time since the test car engine start moment. 


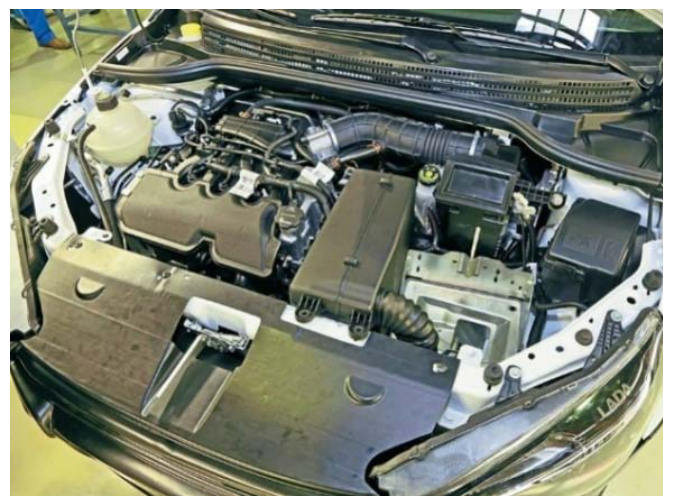

Fig. 1. General view of the test car engine compartment.

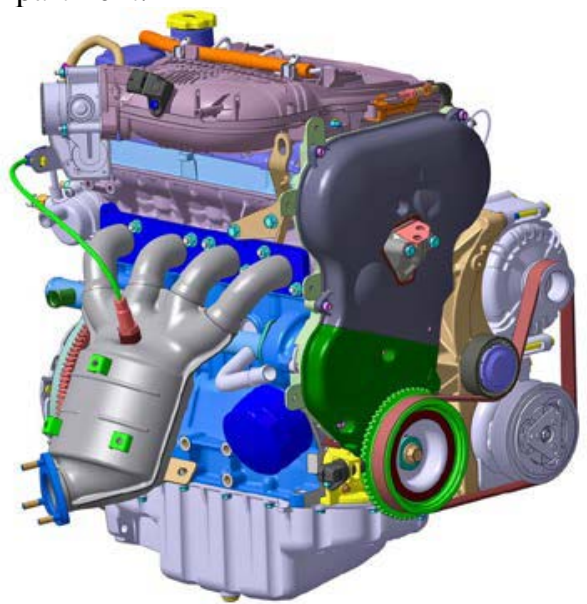

Fig. 2. General view of the engine VAZ21129.

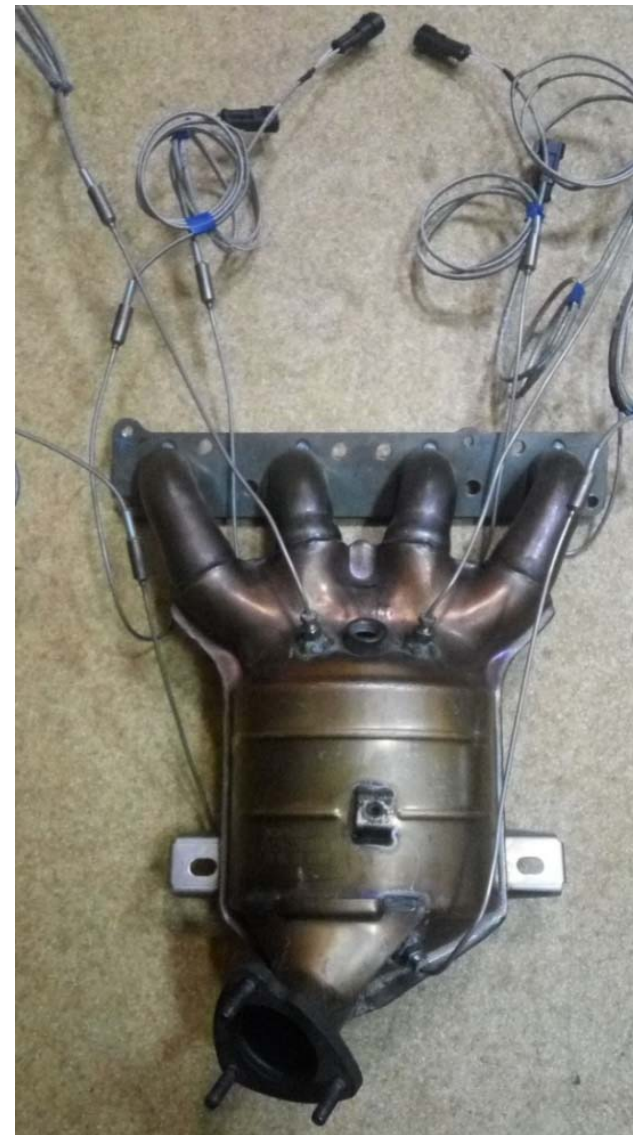

Fig. 3. Appearance of the catalytic converter with integrated thermocouples.

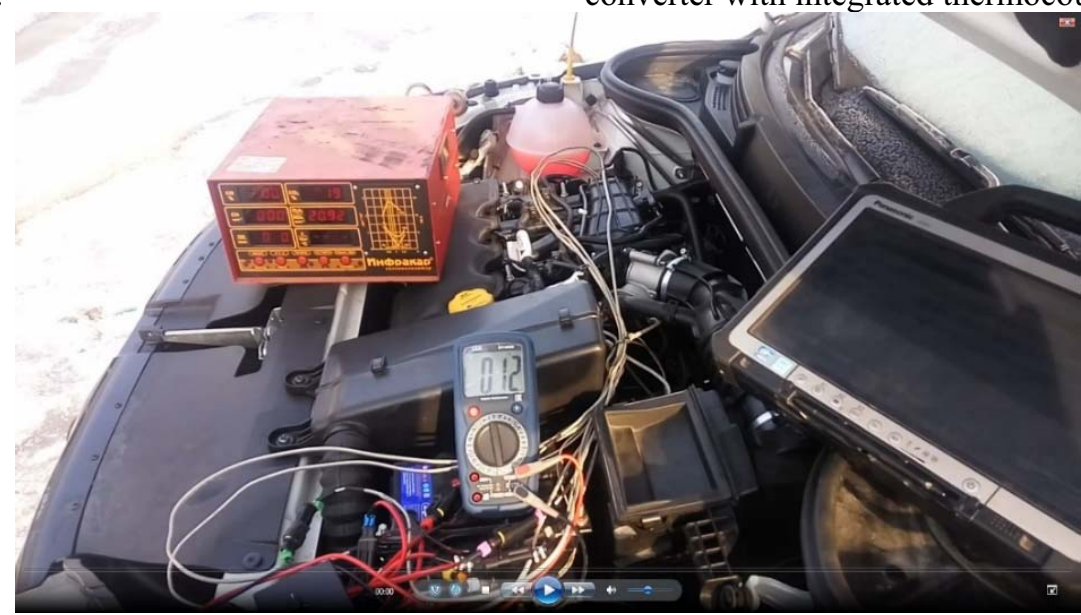

Fig. 4. General view of the experimental setup. 
Experimental studies were conducted on a stationary car in the conditions of its direct operation at an ambient temperature of -30 to $+1{ }^{\circ} \mathrm{C}$ and engine crankshaft speed from 825 to $1369 \mathrm{rpm}$.

Minimum stable crankshaft speed mode was selected, which is the most common one during cold engine starts, as a diagnostic condition.

There is average wind speed in city about $5 \mathrm{~m} / \mathrm{s}$ and even less in the intra-quarter territories, where it influence is minimal. Therefore, in present study the wind influence factor on the time to reach efficient operating mode of catalytic converter was not count.

The number of observations provides a confidence probability of 0.95 and a marginal sampling error of 0.1 .

\section{Theory}

Scientists and practical workers were engaged in the work of a catalytic converter for automobile internal combustion engines.

In the papers $[4,5]$ experiment studies of temperature change of exhaust system were carried out on the "idle" car engine operation mode, however, in order to solve the problem of formation an increased amount of condensate in the car exhaust system at low ambient temperature.

Kirasirov O.M., Nesterenko G.A., Starichkov V.I. [6] carried out experimental observations under certain driving modes. It made possible to give practical recommendations for neutralizing the exhaust gases of internal combustion car engines.

Erokhov V.I., Odinokova I.V. [7] have been solving problem of the reducing NOx emissions prospects to ensure the Euro- 5 standard by selecting an adsorption-catalytic converter.

In the paper [8] studies for determination of prospect catalytic converter system carried out, which is used for neutralization exhaust gases toxic components, in the first NOx, dispersed particles as well as hydrocarbons.

Shirman, Tanya; Toops, Todd J.; Shirman, Elijah [9] focused on tightening the regulations related to the treatment of vehicle exhaust gases, together with the continuous improvement of the engine design. This results in lower engine operating temperatures and inadvertently releases the overwhelming amount of pollutants during a cold start.

Bedi, U., Chauhan, S. [10] concluded that volatile organic compounds are released in significant quantities from catalytic converters during the catalyst warm-up period.

In the paper [11], the influence of the heating mode and ambient temperature on the fuel efficiency and harmful engine emissions was established. The studies were performed using a heat accumulator.

Papetti, V., Dimopoulos Eggenschwiler, P. [12] carried out research during cold engine starts and obtained indicators of heat and mass transfer with chemical reactions based on numerical modeling in OpenFOAM and dimensionless analysis to assess the effect of various operating parameters, the geometry of the neutralizer grate.

Rajendran, R., Logesh, U., Praveen, N.S., Subbiah, G. [13] also have been solving the problem of reducing ambient air pollution by calculating a model of a catalytic converter with an optimal design and using zirconium and aluminum oxide in it.

It was found that the increase in efficiency of automobiles exhaust gases neutralizers was performed at the expense of the information management tools in the system [14].

In relation to the issue of increasing the efficiency of the catalytic converter for synthesis gas, the temperature and composition of the exhaust gases of piston and rotary piston internal combustion engines [15], including emissions of $\mathrm{CO}, \mathrm{CH}$ and $\mathrm{NOx}$ [16], were studied. 
Previous studies are not fully devoted to solving the problem of determining the dependence of the warm-up time change of the catalytic converter in the open storage car conditions, taking into account the provision of the required $\mathrm{CO}$ and $\mathrm{CH}$ content values in the exhaust gases.

\section{Results}

The analysis of the results of the author's experimental studies made it possible to determine the effect of the temperature of open storage of cars on the warm-up time of the catalytic converter.

The results of experimental studies have shown that the efficiency of $\mathrm{CO}$ and $\mathrm{CH}$ neutralization increases intensively with a temperature increase in the catalytic converter the points of rapid decrease in the $\mathrm{CO}$ and $\mathrm{CH}$ content coincide with temperature increase in the catalytic converter.

It is necessary to agree with the studies that the amount of $\mathrm{CO}$ and $\mathrm{CH}$ emissions increases with a decrease in engine temperature [17].

When the catalyst temperature reaches $3000 \mathrm{C}$, the content of $\mathrm{CO}$ and $\mathrm{CH}$ will correspond to the standards for the emission of gases into the atmosphere (Fig. 5).

The obtained dependences of the dynamics in temperature changes of the catalytic converter internal structure at different ambient temperatures with a high degree of accuracy (determination coefficient R2 $>0.99$ ) are approximated by a power function (the average approximation error does not exceed 8.9\%) (Fig.5).

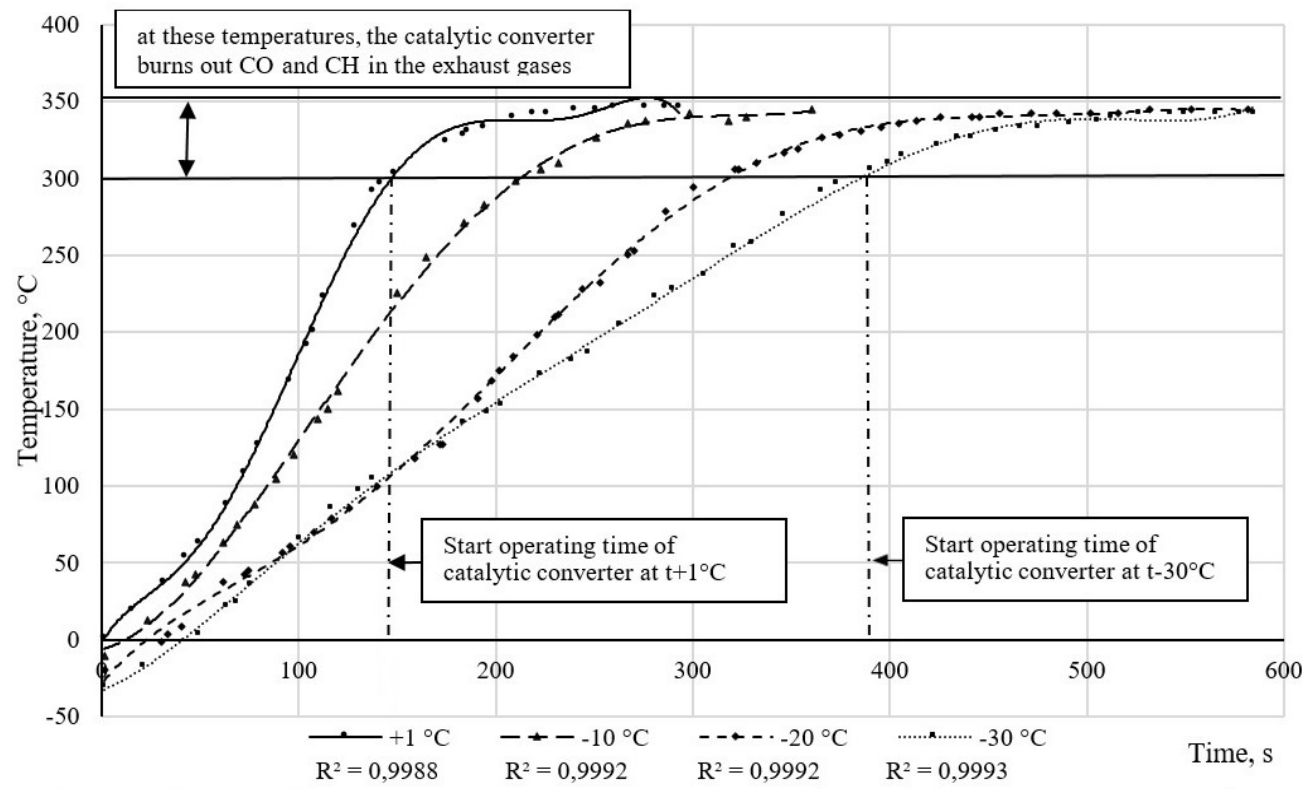

Fig. 5. Influence of the temperature of open storage cars on the catalytic converter warm-up time, taking into account current requirements of the standards for $\mathrm{CO}$ and $\mathrm{CH}$ content in car engine exhaust gases

Tests of the LADA VESTA car with the VAZ-21129 engine showed a sufficiently high degree of influence of ambient air temperature on time to achieve effective operation of the neutralizer. 
Reducing the ambient temperature at the time of internal combustion engine cold start from $+1{ }^{\circ} \mathrm{C}$ to $-30{ }^{\circ} \mathrm{C}$ increased the time to achieve effective operation for $\mathrm{CO}$ by 2.5 times (from 2 to 5 minutes), and for $\mathrm{CH}$ by 2.8 times (from 2.08 to 5.8 minutes).

\section{Conclusions}

The influence of the temperature of open storage of cars on the catalytic converter warm-up time was experimentally established, taking into account the current requirements of the standards for $\mathrm{CO}$ and $\mathrm{CH}$ content in the passenger car engine exhaust gases.

The warm-up time is determined at various low ambient temperatures.

The application of the obtained results in the practice of operating cars equipped with internal combustion engines with forced ignition will supplement UNECE Regulation No. 83-06 and improve the type VI test method (monitoring the average level of carbon monoxide and hydrocarbon emissions in exhaust gas emissions after starting a cold engine at low ambient temperature).

\section{References}

1. S.S. Bell, V.I. Erokhov Catalytic neutralization of automobile exhaust gases. Ecology and industry of Russia, №(7), pp. 55-57 (2012)

2. N.G. Pevnev, A.V. Zaloznov Compliance of the methodology of state tests of threecomponent neutralizers of exhaust gases with real operating conditions, Scientific peerreviewed journal "Bulletin of SibADI", 4(50), pp. 70-77, (2016)

3. A.V. Zaloznov, N.G. Pevnev Description of the mathematical model for calculating the time of the non-stationary heating process of the catalytic converter of the exhaust gases, Scientific peer-reviewed journal "Bulletin of SibADI" 56(4-5(56-57)), pp, 25-36, (2017).

4. M.G. Boyarshinov, N.V. Lobov, N.I. Kuznetsov, A.O. Martemyanov The temperature mode of the vehicle exhaust system at low temperatures, Transport. Transport facilities. Ecology, № 3, pp. 5-15, (2018)

5. N.I. Kuznetsov, M.G. Boyarshinov Investigation of the temperature state of the surface of the exhaust gas system of a vehicle when driving along a test driving cycle at low temperatures, Transport. Transport facilities. Ecology, № 1, pp. 45-53, (2020)

6. O.M. Kirasirov, G.A. Nesterenko, V.I. Starichkov. Neutralization of exhaust gases from internal combustion engines (ICE) of cars, National Association of Scientists, № 5-2 (10), pp. 87-91, (2015)

7. V.I. Erokhov, I.V. Odinokova Improving the environmental parameters of gas-diesel vehicles, Alternative fuel transport, №2(50), pp. 57-66, (2016)

8. V.L. Khimich, N.A. Khripach, L.Yu. Lezhnev, B.A. Papkin, F.A. Shustrov, D.A. Ivanov, V.I.Sonkin, I.A. Papkin Neutralization of toxic components of exhaust gases from internal combustion engines to the level of promising environmental standards, Proceedings of the Nizhny Novgorod State Technical University R.E. Alekseeva, №1(94), pp. 28-34, (2012).

9. Tanya Shirman, Todd J. Toops, Elijah Shirman, Raspberry colloid-templated approach for the synthesis of palladium-based oxidation catalysts with enhanced hydrothermal stability and low-temperature activity, CATALYSIS TODAY, Issue: 360 , pp. 241-251, (2021)

10. U. Bedi, S. Chauhan Mathematical modeling of automotive catalytic converter for catalytic combustion of the volatile organic compound (voc) methane, Journal of Physics: Conference Series. 1706(1), 012035, pp. 114-118, (2020) 
11. N.P. Tsyuman, I.V. Gritsuk, M.Smeshek Investigation of the use of a heat accumulator to reduce harmful emissions of a car engine by accelerated post-start heating of the catalytic converter, Bulletin of the National Transport University, Issue 3(42), pp. 200-212, (2018)

12. V. Papetti, Eggenschwiler P. Dimopoulos, Torre A. Della, A. Ortona, G. Koltsakis Instationary heat and mass transfer phenomena in additive manufactured open cell polyhedral structures for automotive catalysis, Chemical Engineering Science, 234, 116448, pp. 200-210, (2021).

13. R. Rajendran, U. Logesh, N.S. Praveen, G. Subbiah, Optimum design of catalytic converter to reduce carbon monoxide emissions on diesel engine, AIP Conference Proceedings, 2311,040011, pp. 54-62 (2020)

14. R.I. Solnitseva, G.I. Korshunova, O.V. Baranova, Closed control system for neutralization of automobile exhaust gases. Information control systems, № 2, pp. 37-42 (2015)

15. E.A. Zakharov, V.A. Alimov, E.G. Safarov, Investigation of the temperature and composition of the exhaust gases of internal combustion engines with spark ignition in order to assess the possibility of thermochemical conversion of fuel into synthesis gas. Energy and Resource Saving: Industry and Transport, № 3 (20), pp. 44-46, (2017)

16. I. Yakoumis, Prometheus: A copper-based polymetallic catalyst for automotive applications. part i: Synthesis and characterization, Materials, 14(3), 622, pp. 1-19, 2021.

17. V.A. Solomin, A.V. Shabanov, A.A. Shabanov, V.M. Kilyushnik, A.V. Mladensky, On the issue of improving the efficiency of the catalytic converter, Izvestiya MGTU MAMI, № 1 (31), pp. 63-71, (2017) 